\title{
KONSEP AHLI WARIS DAN AHLI WARIS PENGGANTI: Studi Putusan Hakim Pengadilan Agama
}

\author{
Diana Zuhroh \\ Institut Agama Islam Negeri (IAIN) Surakarta \\ e-mail: dianazuhroh@yahoo.com
}

\begin{abstract}
There is a fundamental difference between the rules in Islamic inheritance jurisprudence with the rules of inheritance in the Compilation of Islamic Law. Islamic inheritance jurisprudence rules, on one hand, give inheritance rights to those who are still alive at the time of the testator died. On the other hand, the rules of inheritance in the Compilation of Islamic Law, as defined in Article 171 (c), give inheritance rights to the person who died earlier than the testator, as an attempt to legitimize "substitute heirs" under Article 185 paragraph (1). This difference was not known by the judges in the Religious Courts that have implemented the Compilation of Islamic Law as one source of their substantive laws. This study revealed that in its decision on the case of inheritance proved that the Judges concerned unconsciously, others with skepticism, citing the aforementioned article as one aspect of their legal considerations in determining the beneficiary status of the applicants/plaintiffs, even if the applicant/plaintiff was is "a direct heir" of the testator. Consequently, the resulting verdict is not supported by proper legal considerations.
\end{abstract}

Ada perbedaan yang mendasar antara aturan waris dalam Ilmu Faraid dengan aturan waris dalam Kompilasi Hukum Islam. Aturan waris Ilmu Faraid memberikan hak waris kepada orang yang masih hidup di saat pewaris meninggal dunia. Sebaliknya, aturan waris Kompilasi Hukum Islam, sebagaimana ditetapkan dalam Pasal 171 huruf (c), memberikan hak waris kepada orang yang meninggal dunia lebih dahulu daripada si pewaris, sebagai upaya melegitimasi "ahli waris pengganti" yang diatur dalam Pasal 185 ayat (1). Perbedaan ini telah luput dari pengamatan para Hakim di lingkungan Peradilan Agama yang telah lama menerapkan Kompilasi Hukum Islam sebagai salah satu sumber hukum materiilnya. Penelitian ini mengungkapkan bahwa dalam sejumlah putusan waris tampak majelis Hakim yang menangani perkara waris tanpa sadar, sebagian lainnya dengan keraguan, mengutip pasal tersebut sebagai salah satu aspek pertimbangan hukum mereka dalam menetapkan status keahliwarisan para pemohon/ penggugat, sekalipun para pemohon/penggugat itu adalah "ahli waris langsung" dari si pewaris. Akibatnya, diktum putusan yang dilahirkan tidak didukung oleh pertimbangan hukum yang benar.

Keywords: religious court; substitute heirs; compilation of islamic law 


\section{Pendahuluan}

Salah satu yang membedakan hukum kewarisan dalam Kompilasi Hukum Islam dari Ilmu Faraid adalah diakomodasinya konsep ahli waris pengganti, sebagaimana tertuang dalam Pasal 185 ayat (1) yang menyebutkan bahwa "ahli waris yang meninggal lebih dahulu daripada si pewaris maka kedudukannya dapat digantikan oleh anaknya." Ilmu Faraid tidak mengenal konsep penggantian posisi ahli waris oleh ahli waris yang lain karena berlaku prinsip bahwa ahli waris yang lebih dekat kekerabatannya dengan pewaris menghalangi ahli waris yang lebih jauh dari menerima warisan. Sebagai gantinya, sistem waris dalam Ilmu Faraid lebih menekankan konsep wasiat dari pewaris kepada kerabat yang tidak dapat menerima bagian waris karena sebab-sebab tertentu. Bahkan, negara modern yang menerapkan hukum waris Islam, seperti Mesir, telah melembagakannya dalam konsep wasiat wajibah. ${ }^{1}$

Konsep ahli waris pengganti dalam sistem kewarisan menurut Kompilasi Hukum Islam diyakini mengadopsi pemikiran salah satu pakar hukum Islam Indonesia, Hazairin, dalam bukunya Hukum Kewarisan Bilateral menurut alQur'an dan Hadis, dimana beliau menggagas konsep ahli waris pengganti dan memberikan makna yang berbeda terhadap pemahaman mayoritas ulama tentang konsep ahli waris. Konsep Hazairin tentang ahli waris pengganti berasal dari penafsiran beliau terhadap kata mawālī yang terdapat pada QS. alNisa' (4) ayat 33.² Beliau menafsirkan kata mawālì sebagai ahli waris karena penggantian, yaitu orang-orang yang menjadi ahli waris karena tidak ada lagi penghubung antara mereka dengan pewaris. ${ }^{3}$ Sebagai contoh, anak dapat menjadi ahli waris dari kakeknya, bersama-sama dengan pamannya yang

${ }^{1} \mathrm{H}$. Ahmad Azhar Basyir, MA., Hukum Waris Islam (Yogyakarta: Universitas Islam Indonesia, 1990), h. 44.

${ }^{2}$ QS. al-Nisa' [4]: 3.

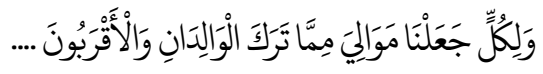

"Bagi tiap-tiap harta peninggalan dari harta yang ditinggalkan ibu bapak dan karib kerabat, Kami jadikan ahli waris-ahli warisnya ...." 32.

${ }^{3}$ Hazairin, Hukum Kewarisan Bilateral menurut al-Qur'an dan Hadis (Jakarta: Tintamas, 1982), h. 
masih hidup, menggantikan kedudukan ayahnya yang telah meninggal lebih dahulu dari si kakek.

Pendapat Hazairin tersebut berbeda dengan pemahaman mayoritas ulama farāild yang berpendapat bahwa istilah mawālì sebagaimana terdapat dalam QS. al-Nisa' ayat 33 berarti ahli waris. Menurut para ulama, ahli waris hanya dibatasi pada orang-orang yang masih hidup di saat pewaris meninggal. Oleh karena itu, selama masih ada ahli waris yang masih hidup dan lebih berhak atas harta warisan, maka keturunan dari ahli waris yang meninggalnya mendahului pewaris tidak berhak atas bagian yang seharusnya diterima oleh orang tuanya jika masih hidup. Sebagai contoh; seorang ayah memiliki dua orang anak laki-laki. Salah seorang anak laki-lakinya meninggal dunia mendahului ayahnya, maka menurut hukum waris Islam anak yang meninggal tersebut bukan ahli waris lagi dari ayahnya. Anak laki-laki yang masih hidup itulah yang menjadi ahli waris jika ayahnya meninggal. Jika anak yang meninggal tersebut memiliki keturunan, maka menurut hukum waris Islam kedudukannya tidak bisa digantikan oleh keturunannya karena mahjūb (terhalang) oleh anak laki-laki pewaris.

Patut diduga, bahwa konsep ahli waris pengganti pada awalnya muncul sebagai akibat dari -salah satunya- pengaruh hukum kolonial (BW) ${ }^{4}$ yang berlaku di Indonesia. Kemudian para pendukung konsep tersebut berupaya mencari landasan teoretis untuk menjustifikasi bahwa konsep ahli waris pengganti adalah konsep yang syar'i, sebagaimana yang telah dilakukan oleh Hazairin dengan penafsirannya terhadap kata mawālī dalam QS. al-Nisa' seperti tersebut di atas.

Demikian halnya dengan para perumus materi hukum waris yang tertuang dalam Kompilasi Hukum Islam. Sebelum merumuskan Pasal 185 ayat (1) ten-

\footnotetext{
${ }^{4}$ Sistem pembagian harta warisan menurut Kitab Undang-Undang Hukum Perdata, atau yang lebih dikenal dengan sebutan BW (Burgerlijk Wetboek), dikenal dua golongan ahli waris, yaitu: ahli waris berdasarkan kedudukan sendiri ( uit eigen hoofed) dan ahli waris berdasarkan penggantian ( $b i j$ plaatsvervulling). Yang disebut terakhir ini diatur dalam pasal 841 sampai pasal 848 BW. Dalam pasal 841 disebutkan bahwa "Penggantian memberikan hak kepada orang yang mengganti untuk bertindak sebagai pengganti dalam derajat dan dalam segala hak orang yang digantikannya." Lihat Hajar M, "Asal Usul Ahli Waris Pengganti dan Implementasi Ahli Waris Pengganti Perspektif Hukum Islam", dalam Asy-Syir'ah Jurnal Ilmu Syari'ah dan Hukum Vol. 50 No.1 Juni 2016, h. 56. Lihat pula Hajar M, "Epistemologi Ahli Waris Pengganti dalam Kompilasi Hukum Islam", dalam Millah Vol. XIV No.1 Agustus 2014.
} 
tang ahli waris pengganti, mereka terlebih dahulu membuat landasan teoritis siapa sebenarnya yang disebut sebagai ahli waris. Sebagaimana tertuang dalam Pasal 171 huruf (c) Kompilasi Hukum Islam, para perumus materi hukum dalam Kompilasi Hukum Islam mendefinisikan bahwa yang disebut sebagai ahli waris adalah "orang yang pada saat meninggal dunia mempunyai hubungan darah atau hubungan perkawinan dengan pewaris, beragama Islam dan tidak terhalang karena hukum untuk menjadi ahli waris." Sepintas, definisi tersebut terkesan biasa dan tidak membawa konsekuensi makna yang substansial tentang siapa ahli waris. Namun bila ditelaah secara mendalam, khususnya pada frase "orang yang pada saat meninggal dunia," ternyata definisi tersebut telah melahirkan konsep ahli waris yang jauh berbeda dengan konsep yang selama ini mendasari definisi siapa yang disebut ahli waris dalam Ilmu Faraid. ${ }^{5}$

Definisi ahli waris dalam Pasal 171 huruf (c) Kompilasi Hukum Islam menjadikan matinya ahli waris (bukan pewaris) sebagai batas kapan seseorang menjadi atau berstatus sebagai ahli waris dari seorang pewaris. Konsekuensi maknanya adalah bahwa orang yang telah meninggal dunia, lebih dahulu sekalipun, asalkan mempunyai hubungan darah atau hubungan perkawinan dengan pewaris, beragama Islam dan tidak terhalang karena hukum untuk menjadi ahli waris, maka dia adalah ahli waris. Lebih jauh, dapat diambil pengertian bahwa oleh karena orang yang telah meninggal dunia lebih dahulu dari pewaris, tidak menghilangkan statusnya sebagai ahli waris, maka kedudukannya dapat digantikan oleh ahli waris lain, dalam hal ini keturunannya (ahli waris pengganti). Dengan demikian, definisi ahli waris dalam Pasal 171 huruf (c) tidak bertentangan, bahkan menjustifikasi, keberadaan konsep ahli waris pengganti yang disebutkan dalam Pasal 185 ayat (1). Definisi ahli waris

\footnotetext{
${ }^{5}$ Menurut Ilmu Faraid, yang dimaksud dengan ahli waris adalah "orang yang pada saat pewaris meninggal dunia mempunyai hubungan darah atau hubungan perkawinan dengan pewaris, beragama Islam dan tidak terhalang karena hukum untuk menjadi ahli waris." Definisi ini dapat disimpulkan dari kualifikasi atau persyaratan yang harus dipenuhi oleh seseorang untuk dapat menjadi ahli waris, sebagaimana ditentukan dalam berbagai literatur hukum waris Islam, yaitu: beragama Islam, masih hidup di saat pewaris meninggal dunia, dan tidak memiliki penghalang menerima waris. Kebalikan dari definisi ahli waris menurut Kompilasi Hukum Islam, yang menjadi penekanan dalam Ilmu Faraid adalah matinya pewaris dan hidupnya ahli waris. Jadi, seseorang bisa berkedudukan sebagai ahli waris jika dia masih hidup di saat pewaris meninggal dunia.
} 
tersebut senyatanya mengandung absurditas, karena orang yang dinyatakan sebagai ahli waris adalah orang yang sudah meninggal dunia, bukan orang yang masih hidup. Namun, nampaknya para perumus materi hukum waris dalam Kompilasi Hukum Islam tidak menyadari hal ini demi melahirkan konsep ahli waris pengganti.

Kendati sistem kewarisan Kompilasi Hukum Islam masih mengandung persoalan yang krusial seperti diuraikan di atas, pada kenyataannya Kompilasi Hukum Islam telah menjadi salah satu sumber hukum materiil di lingkungan Peradilan Agama. Sejak diberlakukannya pada tahun 1991 hingga saat ini telah lahir sejumlah putusan yang merujuk kepada Kompilasi Hukum Islam, tidak terkecuali dalam bidang hukum warisnya. Tulisan ini berusaha menelaah putusan-putusan Hakim di lingkungan Peradilan Agama yang terkait dengan kasus-kasus atau perkara-perkara pembagian waris baik yang bersifat sengketa maupun permohonan penetapan tanpa sengketa, dengan tujuan untuk mengetahui sejauh mana Hakim-Hakim Pengadilan Agama menyadari dan memahami keberadaan masalah dalam hukum waris yang tertuang dalam Kompilasi Hukum Islam, serta bagaimana pula implikasinya terhadap putusan-putusan yang mereka lahirkan.

Tulisan ini merupakan hasil penelitian normatif terhadap putusan Hakim Pengadilan Agama tentang yang terkait konsep ahli waris yang berimplikasi dalam penentuan konsep ahli waris pengganti. Adapun penulisan ini bertujuan untuk: pertama, mendeskripsikan konsep Hakim Pengadilan Agama dalam beberapa putusannnya tentang konsep ahli waris dalam kandungan Pasal 171 huruf (c) Kompilasi Hukum Islam dalam kaitannya dengan ketentuan ahli waris pengganti dalam Pasal 185 ayat (1). Kedua, implikasi dari pemahaman Hakim atas kandungan dan hubungan kedua pasal tersebut dalam penetapan atau putusan waris yang dijatuhkan.

\section{Putusan Hakim tentang Ahli Waris dan Ahli Waris Pengganti}

Penelitian ini menganalisis tujuh sampel penetapan/putusan Pengadilan Agama dari berbagai wilayah hukum Pengadilan Tinggi Agama, terdiri dari tiga (3) perkara permohonan penetapan ahli waris dan empat (4) perkara gugatan waris. Permohonan penetapan ahli waris adalah perkara yang tidak mengandung sengketa dimana si pemohon atau para pemohon hanya meminta 
Pengadilan Agama untuk menetapkan siapa saja ahli waris dari seseorang yang telah meninggal dunia. Adapun gugatan waris adalah perkara penyelesaian sengketa pembagian harta warisan dimana penggugat atau para penggugat meminta Pengadilan Agama untuk melakukan pembagian kepada seluruh ahli waris atas suatu harta peninggalan yang dikuasai secara sepihak oleh salah satu atau beberapa ahli waris yang dalam perkara didudukkan sebagai pihak tergugat. Dari ketujuh putusan tersebut, dua di antaranya adalah tentang penyelesaian sengketa waris yang subjek hukumnya terdiri dari "ahli waris langsung" (eigen hoofde) dan "ahli waris pengganti" (plaatsvervulling), sedangkan selebihnya tentang penyelesaian permohonan dan gugatan waris yang subjek hukumnya hanya terdiri dari ahli waris langsung. Berikut adalah daftar perkara-perkara dimaksud:

\section{Tabel I.}

\section{Putusan Ahli Waris dan Ahli Waris Pengganti}

\begin{tabular}{|c|c|c|c|}
\hline No. & $\begin{array}{c}\text { Nomor } \\
\text { Putusan/Penetapan }\end{array}$ & Jenis Perkara & Subjek Hukum \\
\hline 1. & 041/Pdt.P/2013/PA.Pdlg & Penetapan Ahli Waris & Ahli waris langsung \\
\hline 2. & 102/Pdt.P/2013/PA.Plh & Penetapan Ahli Waris & Ahli waris langsung \\
\hline 3. & 049/Pdt.P/2012/PA.Pas & Penetapan Ahli Waris & Ahli waris langsung \\
\hline 4. & 17/Pdt.G/2012/PA.Sgr & Gugatan Waris & Ahli waris langsung \\
\hline 5. & 443/Pdt.G/2013/PA.Mdn & Gugatan Waris & Ahli waris langsung \\
\hline 6. & 809/Pdt.G/2012/PA.Pdg & Gugatan Waris & $\begin{array}{l}\text { Ahli waris langsung dan } \\
\text { ahli waris pengganti }\end{array}$ \\
\hline 7. & 186/Pdt.G/2012/PA.Bji & Gugatan Waris & $\begin{array}{l}\text { Ahli waris langsung dan } \\
\text { ahli waris pengganti }\end{array}$ \\
\hline
\end{tabular}

\section{Penetapan Nomor 041/Pdt.P/2013/PA.Pdlg}

Penetapan tersebut merupakan penetapan Pengadilan Agama Pandeglang, wilayah Pengadilan Tinggi Agama Banten, atas perkara permohonan penetapan ahli waris. Para pemohon terdiri dari dua orang anak kandung yang memohon ditetapkan sebagai ahli waris dari ibunya, Warsem binti Marca, yang telah meninggal dunia.

Majelis Hakim yang menangani perkara tersebut telah mengabulkan permohonan para pemohon karena terbukti para pemohon berkedudukan sebagai anak kandung dari almarhumah Warsem binti Marca. Dalam per- 
timbangan hukumnya, majelis Hakim menyatakan bahwa para pemohon merupakan subjek hukum sebagaimana dimaksud dalam pasal 171 huruf (c) Kompilasi Hukum Islam.

\section{Penetapan Nomor 102/Pdt.P/2013/PA.Plh}

Penetapan tersebut merupakan penetapan Pengadilan Agama Pelaihari, wilayah Pengadilan Tinggi Agama Kalimantan Selatan, atas perkara permohonan penetapan ahli waris. Para pemohon terdiri dari dua orang anak kandung, suami, dan ayah kandung yang memohon ditetapkan sebagai ahli waris dari Ipah binti Astra Winata, yang telah meninggal dunia tahun 2013.

Majelis Hakim yang menangani perkara tersebut telah mengabulkan permohonan para pemohon karena terbukti para pemohon berkedudukan sebagai suami, anak kandung, dan ayah kandung dari almarhumah Ipah binti Astra Winata. Dalam pertimbangan hukumnya majelis Hakim menyatakan bahwa para pemohon berkapasitas sebagai ahli waris sebagaimana Pasal 171 huruf (c) Kompilasi Hukum Islam, ahli waris adalah orang yang pada saat meninggal dunia mempunyai hubungan darah atau hubungan perkawinan dengan pewaris, beragama Islam dan tidak terhalang karena hukum untuk menjadi ahli waris.

\section{Penetapan Nomor 049/Pdt.P/2012/PA.Pas}

Penetapan tersebut merupakan penetapan Pengadilan Agama Pasuruan, wilayah Pengadilan Tinggi Agama Jawa Timur, atas perkara permohonan penetapan ahli waris. Para pemohon terdiri dari tiga orang anak kandung, istri, dan ibu kandung yang memohon ditetapkan sebagai ahli waris dari Fulan, yang telah meninggal dunia.

Majelis Hakim yang menangani perkara tersebut telah mengabulkan permohonan para pemohon karena terbukti para pemohon berkedudukan sebagai istri, anak kandung, dan ibu kandung dari almarhum Fulan. Dalam pertimbangan hukumnya, majelis Hakim mengutip batasan ahli waris dalam ketentuan Pasal 171 huruf (c) Kompilasi Hukum Islam dengan penambahan kata "pewaris" sehingga berbunyi: ahli waris adalah orang yang pada saat pewaris meninggal dunia mempunyai hubungan darah atau hubungan perkawinan dengan pewaris, beragama Islam dan tidak terhalang karena hukum untuk menjadi ahli waris. 
Diana Zuhroh

\section{Putusan Nomor 17/Pdt.G/2012/PA.Sgr}

Putusan tersebut merupakan putusan Pengadilan Agama Singaraja, wilayah Pengadilan Tinggi Agama Mataram, atas perkara gugat waris. Penggugat dan tergugat merupakan dua orang bersudara yang bersengketa mengenai tanah warisan dari almarhum ayah mereka yang dikuasai secara sepihak oleh tergugat.

Majelis Hakim yang menangani perkara tersebut telah mengabulkan gugatan penggugat sebagian dan tidak menerima selebihnya. Adapun tuntutan Penggugat yang dikabulkan adalah tentang permohonan agar penggugat dan tergugat dinyatakan sebagai ahli waris dari si pewaris, Maensun. Dalam pertimbangan hukumnya majelis Hakim mengutip definisi ahli waris dalam ketentuan Pasal 171 huruf (c) Kompilasi Hukum Islam dengan penambahan kata "pewaris" sama seperti dalam kasus perkara Nomor 049/Pdt.P/ 2012/PA.Pas di atas.

\section{Putusan Nomor 443/Pdt.G/2013/PA.Mdn}

Putusan tersebut merupakan putusan Pengadilan Agama Medan, wilayah Pengadilan Tinggi Agama Sumatera Utara, atas perkara gugat waris. Para penggugat dan para tergugat merupakan anak-anak dari tiga saudara kandung pewaris yang tidak punya keturunan, dimana ketiga orang saudara kandung tersebut telah meninggal lebih dahulu daripada si pewaris.

Majelis Hakim yang menangani perkara tersebut telah mengabulkan gugatan penggugat karena terbukti penggugat dan salah satu tergugat adalah ahli waris dari pewaris, dalam hal ini sebagai așābah. Dalam pertimbangan hukumnya, ketika mendefinisikan ahli waris majelis Hakim tidak menyebutkan pasal yang dirujuk, akan tetapi melihat redaksinya ternyata sama persis dengan definisi ahli waris dalam Pasal 171 huruf (c) Kompilasi Hukum Islam yang berbunyi "Ahli waris adalah orang yang pada saat meninggal mempunyai hubungan darah, atau hubungan perkawinan dengan pewaris, beragama Islam dan tidak terhalang karena hukum untuk menjadi ahli waris."

\section{Putusan Nomor 809/Pdt.G/2012/PA.Pdg}

Putusan tersebut merupakan putusan Pengadilan Agama Padang, wilayah Pengadilan Tinggi Agama Sumatera Barat, atas perkara gugat waris. Para penggugat merupakan anak kandung pewaris berlawanan dengan para ter- 
gugat yang merupakan anak-anak dari saudara kandung para penggugat (cucu dari si pewaris), dimana saudara kandung para penggugat tersebut telah meninggal lebih dahulu daripada si pewaris.

Majelis Hakim yang menangani perkara tersebut telah mengabulkan gugatan penggugat karena terbukti para penggugat dan para tergugat adalah sama-sama ahli waris dari si pewaris, dimana para penggugat berkedudukan sebagai anak kandung (ahli waris langsung) sedangkan para tergugat adalah sebagai cucu (ahli waris pengganti). Dalam pertimbangan hukumnya majelis Hakim menyatakan bahwa untuk ditetapkan sebagai ahli waris sebagaimana dimaksudkan dalam Pasal 171 huruf (c) juncto Pasal 173 Kompilasi Hukum Islam harus memenuhi ketentuan bahwa ahli waris punya hubungan darah atau hubungan perkawinan dengan pewaris, beragama Islam dan tidak terhalang karena hukum untuk menjadi ahli waris.

\section{Putusan Nomor 186/Pdt.G/2012/PA.Bji}

Putusan tersebut merupakan putusan Pengadilan Agama Binjai, wilayah Pengadilan Tinggi Agama Sumatera Utara, atas perkara gugat waris. Para penggugat merupakan anak kandung pewaris berlawanan dengan para tergugat yang merupakan anak-anak dari saudara kandung para penggugat (cucu dari si pewaris), dimana saudara kandung para penggugat tersebut telah meninggal lebih dahulu daripada si pewaris.

Majelis Hakim yang menangani perkara tersebut telah mengabulkan gugatan para penggugat karena terbukti Penggugat berkedudukan sebagai anak kandung si pewaris (ahli waris langsung). Di samping itu, majelis Hakim juga menetapkan para tergugat sebagai ahli waris dari si pewaris menggantikan posisi ibunya yang telah meninggal lebih dahulu dari si pewaris (ahli waris pengganti). Dalam pertimbangan hukumnya majelis Hakim merujuk kepada definisi ahli waris dalam Pasal 171 huruf (c) Kompilasi Hukum Islam untuk ahli waris langsung, dan merujuk Pasal 185 ayat (1) untuk ahli waris pengganti.

\section{Implikasi Konsep Ahli Waris}

Dari uraian di atas, ternyata bahwa semua putusan/penetapan mengutip langsung atau setidaknya merujuk kepada Pasal 171 huruf (c) Kompilasi Hukum Islam ketika majelis Hakim mencari landasan tentang siapa yang dapat 
menjadi ahli waris, baik dalam perkara yang subjek hukumnya ahli waris langsung maupun ahli waris pengganti. Perbedaannya, sebagian majelis Hakim mengambil definisi ahli waris dari pasal tersebut secara utuh atau apa adanya, sedangkan sebagian lainnya dengan melakukan modifikasi, yakni dengan menyisipkan atau menambahkan kata "pewaris" ke dalam definisi, seperti dalam perkara Nomor 049/Pdt.P/2012/PA.Pas dan perkara Nomor 17/Pdt.G/ 2012/PA.Sgr. Perbedaan sikap majelis Hakim ini menjadi indikasi kuat bahwa ada kejanggalan dalam definisi ahli waris menurut Pasal 171 huruf (c) Kompilasi Hukum Islam, sebab seandainya tidak demikian tentu tidak perlu muncul sikap memodifikasi.

Kendati demikian, baik majelis Hakim yang mengambil definisi ahli waris secara apa adanya maupun yang memodifikasi, semuanya sama-sama tidak menyadari hakikat definisi ahli waris menurut Pasal 171 huruf (c) Kompilasi Hukum Islam dalam kaitannya dengan materi Pasal 185 ayat (1) Kompilasi Hukum Islam tentang ahli waris pengganti. ${ }^{6}$ Hal ini terbukti dari, pertama, dalam putusan/penetapan perkara waris yang semua subjek hukumnya terdiri dari ahli waris langsung majelis Hakim tetap merujuk definisi ahli waris dalam Pasal 171 huruf (c) Kompilasi Hukum Islam sebagai pertimbangan hukum. Padahal, seperti telah diuraikan di awal hakikat definisi ahli waris menurut Pasal 171 huruf (c) tidak bisa dipisahkan dengan keberadaan ketentuan tentang ahli waris pengganti dalam Pasal 185 ayat (1). Dengan kata lain, definisi tersebut tidak relevan untuk dijadikan rujukan dalam perkara waris yang subjek hukumnya adalah ahli waris langsung. Kedua, dalam putusan-putusan perkara waris yang subjek hukumnya bercampur antara ahli waris langsung dengan ahli waris pengganti, yakni Nomor 443/Pdt.G/2013/PA.Mdn, Nomor 809/Pdt.G/2012/PA.Pdg, dan Nomor 186/Pdt.G/2012/PA.Bji, majelis Hakim juga merujuk definis ahli waris dalam Pasal 171 huruf (c), tetapi tidak dalam konteks mempertimbangkan kedudukan subjek hukum ahli waris pengganti secara khusus, melainkan mempertimbangkan

\footnotetext{
${ }^{6}$ Lihat hasil penelitian Fatimah Zuhrah yang menyebutkan bahwa ahli waris pengganti merupakan hasil konstruksi hukum Islam di Indonesia yang sesungguhnya tidak ada ketentuannya dalam al-Qur'an. Fatimah Zuhrah, "Ahli Waris Pengganti dan Pembaruan Hukum Kewarisan Islam Indonesia: Kajian Sosiologis dan Yuridis", dalam Jurnal Penelitian Medan Agama Vol. 8 No. 2, Tahun 2016.
} 
kedudukan semua subjek hukum, baik mereka itu ahli waris langsung maupun ahli waris pengganti, tanpa menguraikan hubungan definisi tersebut dengan materi Pasal 185 ayat (1).

Ketidakpahaman Hakim tentang hakikat definisi ahli waris menurut Pasal 171 huruf (c) Kompilasi Hukum Islam dalam kaitannya dengan materi Pasal 185 ayat (1) tentang ahli waris pengganti telah melahirkan putusan-putusan yang rancu, dimana amar putusan tidak didukung oleh pertimbangan hukum yang benar. Seperti telah diuaraikan di atas, tujuh putusan/penetapan yang penulis analisis semua pemohon/penggugatnya berkedudukan sebagai ahli waris langsung, dan oleh majelis Hakim semuanya dinyatakan terbukti sebagai ahli waris yang sah dari si pewaris masing-masing. Sementara itu, salah satu pertimbangan majelis Hakim dalam menetapkan para pemohon/penggugat sebagai ahli waris adalah Pasal 171 huruf (c) Kompilasi Hukum Islam yang berbunyi: "Ahli waris adalah orang yang pada saat meninggal mempunyai hubungan darah, atau hubungan perkawinan dengan pewaris, beragama Islam dan tidak terhalang karena hukum untuk menjadi ahli waris." Pertimbangan ini jelas tidak tepat, karena menurut pasal tersebut ahli waris adalah orang yang sudah meninggal dunia, sedangkan para pemohon/penggugat adalah berkedudukan sebagai ahli waris langsung, bukan menggantikan ahli waris yang sudah meninggal (ahli waris pengganti). Seharusnya yang dijadikan pertimbangan majelis Hakim adalah definisi ahli waris menurut Ilmu Faraid, yaitu: "Ahli waris adalah orang yang pada saat pewaris meninggal mempunyai hubungan darah, atau hubungan perkawinan dengan pewaris, beragama Islam dan tidak terhalang karena hukum untuk menjadi ahli waris." Kedua macam definisi tersebut membawa konotasi makna yang jauh berbeda sehingga tidak dapat dipertukarkan. Definisi menurut Pasal 171 huruf (c) hanya mencakup ahli waris pengganti, sedangkan definisi menurut Ilmu Faraid hanya mencakup ahli waris langsung.

Dalam konteks perkara waris yang diajukan secara kontentiosa (mengandung unsur sengketa antara penggugat dengan tergugat), putusan-putusan yang rancu seperti di atas dapat membawa implikasi yang jauh lebih serius, yakni merugikan salah satu pihak berperkara. Misalnya, dalam putusan dengan nomor perkara 809/Pdt.G/2012/PA.Pdg (kasus 6) dan nomor perkara 186/Pdt.G/2012/PA.Bji (kasus 7) para tergugat menjadi pihak yang dirugikan 
karena dikalahkan. Padahal, seandainya majelis Hakim konsisten dengan pertimbangan hukumnya, para penggugatlah yang seharusnya menjadi pihak yang kalah. Seperti diuraikan di atas, dalam dua kasus tersebut para penggugat secara teori berkedudukan sebagai ahli waris langsung, sebaliknya para tergugat berkedudukan sebagai ahli waris pengganti. Majelis Hakim dalam pertimbangan hukumnya dengan jelas telah merujuk kepada definisi ahli waris dalam Pasal 171 huruf (c) Kompilasi Hukum Islam yang secara substansial hanya berkenaan dengan ahli waris pengganti. Oleh sebab itu, para tergugat karena terbukti sebagai ahli waris, meskipun hanya sebagai pengganti, tidak seharusnya menjadi pihak yang kalah, dan sebaliknya para penggugatlah yang seharusnya menjadi pihak yang kalah, dengan ditolak gugatannya, karena mereka tidak terbukti sebagai ahli waris berdasarkan pasal tersebut.

Kondisi inkonsistensi putusan dalam menetapkan status ahli waris sebenarnya dapat dihindari seandainya majelis Hakim yang menangani perkara gugatan waris bersikap kritis terhadap definisi ahli waris dalam Pasal 171 huruf (c) Kompilasi Hukum Islam. Majelis Hakim tidak perlu memaksakan diri mengutip definisi ahli waris dari pasal tersebut. Untuk membuat landasan hukum tentang siapa yang dapat dinyatakan sebagai ahli waris, majelis Hakim misalnya dapat membuat rumusan sendiri secara induktif dari syarat-syarat warisan yang telah tertuang dalam kitab atau buku-buku tentang Ilmu Faraid. Majelis Hakim juga dapat langsung mengutip ayat-ayat al-Qur'an atau Hadis Nabi saw yang relevan untuk dijadikan sebagai landasan hukum. Pasal 171 huruf (c) Kompilasi Hukum Islam menurut penulis tidak dapat digunakan sebagai landasan hukum menentukan status keahliwarisan seseorang karena pasal tersebut menjadikan matinya ahli waris (bukan matinya pewaris) sebagai batas kapan seseorang menjadi atau berstatus sebagai ahli waris dari seorang pewaris.

Penulis berasumsi bahwa ketidakpahaman Hakim akan hakikat atau substansi definisi ahli waris yang dibawa oleh Pasal 171 huruf (c) dalam korelasinya dengan keberadaan Pasal 185 ayat (1) dalam Kompilasi Hukum Islam bukan hanya kasus pada beberapa atau sebagian Hakim seperti fakta yang tercermin dari tujuh sampel putusan/penetapan di atas, akan tetapi agaknya juga menjadi fenomena umum Hakim di lingkungan Peradilan Agama pada semua tingkatan. Keberadaan pasal tentang ahli waris pengganti dalam Kompilasi Hukum Islam sebenarnya bukan tanpa perhatian dari para Hakim, 
baik pada Pengadilan Tinggi Agama maupun Mahkamah Agung. Telah ada forum-forum diskusi dan pertemuan yang melibatkan Hakim-Hakim Peradilan Agama pada semua tingkatan untuk membahas berbagai persolan hukum dan menyusun buku pedoman, dimana salah satu materi bahasannya adalah masalah ahli waris pengganti. Akan tatapi, semua pembahasan tersebut sejauh ini hanya terfokus kepada batasan dan jangkauan pengertian ahli waris pengganti yang dimaksud oleh Pasal 185 ayat (1) Kompilasi Hukum Islam, tanpa pernah menghubungkannya dengan Pasal 171 huruf (c). Misalnya, tim penyusun Buku Pedoman Administrasi dan Teknis Peradilan Agama, atau lebih dikenal dengan sebutan Buku II, yang menjadi acuan bagi seluruh aparat Peradilan Agama, telah melakukan beberapa kali revisi atas buku tersebut, dimana sejak Edisi Tahun 2007 tim mulai memasukan materi tentang ahli waris pengganti. Menurut buku ini, ahli waris pengganti (plaatsvervulling) adalah ahli waris yang diatur dalam Pasal $185 \mathrm{KHI}$, yaitu ahli waris pengganti/ keturunan dari ahli waris yang disebutkan dalam Pasal $174 \mathrm{KHI}$. Di antaranya keturunan dari anak laki-laki atau anak perempuan, keturunan dari saudara laki-laki/perempuan, keturunan dari paman, keturunan dari kakek dan nenek, yaitu bibi dan keturunannya (paman walaupun keturunan kakek dan nenek bukan ahli waris pengganti karena paman sebagai ahli waris langsung yang disebut dalam Pasal $174 \mathrm{KHI}$ ). ${ }^{7}$ Penjelasan ini lebih lanjut dipertegas lagi dalam Buku II Edisi Tahun 2010 dengan perincian yang limitatif. Menurut buku ini, kelompok ahli waris yang mendapat bagian sebagai ahli waris pengganti hanyalah: (1) Keturunan dari anak mewarisi bagian yang digantikan; (2) Keturunan dari saudara laki-laki/perempuan (sekandung, seayah atau seibu) mewarisi bagian yang digantikannya; (3) Kakek dan nenek dari pihak ayah mewarisi bagian dari ayah, masing-masing berbagi sama; (4) Kakek dan nenek dari pihak ibu mewarisi bagian dari ibu, masing-masing berbagi sama; (5) Paman dan bibi dari pihak ayah beserta keturunannya mewarisi bagian dari ayah apabila tidak ada kakek dan nenek dari pihak ayah; (6) Paman dan bibi dari pihak ibu beserta keturunannya mewarisi bagian dari ibu apabila tidak ada kakek dan nenek dari pihak ibu. ${ }^{8}$

\footnotetext{
7 Pedoman Teknis Administrasi Dan Teknis Peradilan Agama (Buku II), ed. 2007 (Mahkamah Agung RI, 2008), h. 168-169.

${ }^{8}$ Pedoman Teknis Administrasi dan Teknis Peradilan Agama (Buku II), ed. revisi 2010 (Mahkamah Agung RI, 2010), h. 167.
} 
Perincian ahli waris pengganti di atas tampaknya justru melahirkan perdebatan baru yang dipicu oleh adanya reaksi penolakan oleh sebagian Hakim yang prihatin dengan liarnya penafsiran tentang siapa ahli waris pengganti yang tercantum dalam Buku II. Sehingga, tidak lama sejak Buku II edisi revisi 2010 diterbitkan perincian ahli waris pengganti dianulir kembali. Dalam Rapat Kerja Nasional (Rakernas) Mahkamah Agung yang diselenggarakan tahun 2010 Komisi II Bidang Urusan Lingkungan Peradilan Agama dalam salah satu kesimpulannya menyatakan bahwa ahli waris pengganti sebagaimana tersebut dalam Pasal 185 KHI pelaksanaannya dibatasi kepada keturunan garis lurus ke bawah sampai dengan derajat cucu. ${ }^{9}$ Demikian juga Rakernas Tahun 2011 dalam salah satu kesimpulannya menyatakan bahwa ahli waris pengganti dalam Buku II supaya direvisi sesuai dengan hasil Rakernas 2010, yaitu hanya kepada cucu saja dan tidak berlaku untuk yang lainnya. ${ }^{10}$

Dari uraian di atas terlihat bahwa perhatian para Hakim di lingkungan Peradilan Agama terhadap ketentuan ahli waris pengganti dalam Kompilasi Hukum Islam hanya terfokus kepada jangkauan pengertian ahli waris pengganti yang dimaksud oleh Pasal 185 ayat (1). Sepengetahuan penulis, hingga saat ini tidak ada pembahasan yang mencoba mendalami eksistensi pasal tersebut dalam kaitannya dengan definisi ahli waris dalam Pasal 171 huruf (c) Kompilasi Hukum Islam. Jika demikian halnya, maka menurut penulis kerancuan dalam putusan-putusan atau penetapan-penetapan Pengadilan Agama yang berkaitan dengan penyelesaian waris masih akan terus berlanjut di masa yang akan datang.

\section{Kesimpulan}

Berdasarkan analisis penulis terhadap fakta-fakta berupa penetapan/ putusan Pengadilan Agama seperti terurai di atas, dapat diambil kesimpulan bahwa:

${ }^{9}$ Rumusan Hasil Diskusi Komisi II Bidang Urusan Lingkungan Peradilan Agama (Hasil Rakernas Tahun 2010), h. 2.

10Permasalahan Hukum pada Pengadilan Tinggi Agama Se-Indonesia dan Mahkamah Syaríyah Aceh (Hasil Rakernas Tahun 2011), h. 6. 
Definisi ahli waris yang tertuang dalam Pasal 171 huruf (c) Kompilasi Hukum Islam yang berbeda dengan definisi menurut Ilmu Faraid adalah sebuah upaya yang direncanakan dari para perumus Kompilasi Hukum Islam untuk melegitimasi keberadaan ahli waris pengganti yang dituangkan dalam Pasal 185 ayat (1). Perbedaan definisi yang sangat halus, karena hanya berbeda satu kata, terbukti tidak disadari atau tidak dipahami oleh sebagian Hakim di lingkungan Peradilan Agama.

Ketidakpahaman Hakim terhadap hakikat definisi ahli waris yang tertuang dalam Pasal 171 huruf (c) Kompilasi Hukum Islam telah melahirkan putusan/ penetapan yang rancu karena diktum putusan tidak didasarkan pada pertimbangan hukum yang benar. Meskipun diktum putusan tersebut benar secara materiil, tetapi secara metodologis tidak bisa dipertanggungjawabkan, dan dalam konteks tertentu dapat merugikan salah satu pihak berperkara. Kerancuan dan inkonsistensi seperti ini bersifat fatal mengingat pertimbangan hukum adalah mahkota dari sebuah putusan.[a]

\section{DAFTAR PUSTAKA}

Arto, Mukti, Hukum Waris Bilateral dalam Kompilasi Hukum Islam, Solo: Balqis Queen, 2009.

Athoillah, Fikih Waris (Metode Pembagian Waris Praktis), Bandung: Yrama Widya, 2013.

Basyir, Ahmad Azhar, Hukum Waris Islam, Yogyakarta: UII Press, 2001.

Hazairin, Hukum Kewarisan Bilateral, Jakarta: Tintamas, 1982.

Hajar M, "Asal Usul Ahli Waris Pengganti dan Implementasi Ahli Waris Pengganti Perspektif Hukum Islam", dalam Asy-Syir'ah Jurnal Ilmu Syari'ah dan Hukum Vol. 50 No.1 Juni 2016.

"Epistemologi Ahli Waris Pengganti dalam Kompilasi Hukum Islam", dalam Millah Vol. XIV No.1 Agustus 2014.

Instruksi Presiden Nomor 1 Tahun 1990 tentang Kompilasi Hukum Islam.

Pedoman Teknis Administrasi dan Teknis Peradilan Agama (Buku II). Jakarta: Direktorat Jenderal Badan Peradilan Agama, 2010.

Penetapan Nomor 041/Pdt.P/2013/PA.Pdlg. 
Diana Zuhroh

Penetapan Nomor 049/Pdt.P/2012/PA.Pas.

Penetapan Nomor 102/Pdt.P/2013/PA.Plh.

Permasalahan Hukum pada Pengadilan Tinggi Agama Se-Indonesia dan Mahkamah Syar'iyah Aceh (Hasil Rakernas Tahun 2011).

Putusan Nomor 17/Pdt.G/2012/PA.Sgr.

Putusan Nomor 186/Pdt.G/2012/PA.Bji.

Putusan Nomor 443/Pdt.G/2013/PA.Mdn.

Putusan Nomor 809/Pdt.G/2012/PA.Pdg.

Al-Qur'an dan Terjemahnya.

Rahman, Fatchur, Ilmu Waris, Bandung: al-Ma'arif, 1981.

Rasyid, Roihan A., artikel "Pengganti Ahli Waris dan Wasiat Wajibah" dalam buku Cik Hasan Bisri (Penyunting), Kompilasi Hukum Islam dan Peradilan Agama dalam Sistem Hukum Nasional, Jakarta: Logos Wacana Ilmu, 1999.

Rumusan Hasil Diskusi Komisi II Bidang Urusan Lingkungan Peradilan Agama (Hasil Rakernas Tahun 2010).

Zuhrah, Fatimah, "Ahli Waris Pengganti dan Pembaruan Hukum Kewarisan Islam Indonesia: Kajian Sosiologis dan Yuridis", dalam Jurnal Penelitian Medan Agama Vol. 8 No. 2, 2016. 